\title{
COMPUTATIONAL STUDIES, EFFICIENT SYNTHESIS AND BIOLOGICAL EVALUATION OF PYRAZOLO[3,4- d]PYRIMIDINES AS POTENT INHIBITORS OF CHRONIC MYELOID LEUKEMIA, LUNG CARCINOMA AND BREAST CARCINOMA
}

\author{
Parnas S. Parmar and Saurabh K. Patel \\ Department of Chemistry, Veer Narmad South Gujarat University, \\ Surat-395007, (Gujarat) India \\ *E-mail: skpatel@vnsgu.ac.in
}

\begin{abstract}
The specially designed pyrazole and pyrazole fused pyrimidines were subjected to the molecular docking studies with aurora kinase A, Hematopoietic cell kinase (hck) and anaplastic lymphoma kinase. The good interactions prompted us to synthesize the newer pyrazole and pyrazolo[3,4-d]pyrimidines. To prove the hypothesis about anticancer activity, the compounds were screened for their cytotoxicity against human cancer cell lines (MCF-7, K-562 and A-549) and compared with standard drugs. The hypothesis was supported as the $\mathrm{IC}_{50}$ values are found in lower micromolar ranges for six compounds and more potent in the case of chronic myeloid leukemia and lung carcinoma.

Keywords: Small Molecule Drug, Kinase Inhibitor, Chronic Myeloid Leukemia, Lung Cancer, Breast Cancer, Antibacterial Activity, Computational Studies.
\end{abstract}

(C) RASĀYAN. All rights reserved

\section{INTRODUCTION}

The small molecule drugs are a revolutionary step in the field of medicinal chemistry due to their higher affinity and specificity towards their intended targets. ${ }^{1}$ The small molecule can interfere with epigenetic modifier protein to perturb DNA-templated processes by targeting chromatin in several ways. ${ }^{2}$ The small molecules mainly fit enzymes, proteins, DNA, RNA and ribosomes ${ }^{3}$ because lower complexity compounds have a higher probability of matching a target protein-binding site. ${ }^{4}$ The small molecules are a new classical approach for blood-brain barrier (BBB), named for its ability to prevent uncontrolled leakage of substance from blood to brain. ${ }^{5,6}$

The oncology drug discoveries grab great attention in drug synthesis and progress in understanding how small molecules can target kinases to cure various types of cancer. 300 genes within the human genome have been found to mutate in cancer because they contribute to the deregulation of the cell cycle, which is often correlated with abnormal division and uncontrolled proliferation of cancer cells. ${ }^{7}$ The deregulations of kinases have been discovered to be intimately involved in the process controlling to tumor cell survival and proliferation. ${ }^{8}$

The cyclin-dependent kinase $\mathrm{s}^{8-10}$ Aurora A, Aurora B kinases ${ }^{11}$ and tyrosine kinases ${ }^{12}$ have been discovered to be thoroughly involved in the process leading to proliferation and survival of tumor cells. This has generated a huge interest in the progress of small molecule kinase inhibitors for the treatment of cancer because their specific inhibition by small molecule and gene suppressing may lead to the eventual death of cancer cells.

Recently both germaline and somatic mutations that stimulate anaplastic lymphoma kinase have been revealed in neuroblastoma, a devastating childhood tumor for which new target therapies are needed. ${ }^{12}$ Activating translocations or mutations of the ALK (anaplastic lymphoma kinase) gene have been identified in several types of cancer, including neuroblastoma, non-small-cell lung cancer anaplastic large-cell lymphoma and inflammatory myofibroblastic tumor. ${ }^{13}$

Rasayan J. Chem., 13(3), 1555-1570(2020)

http://dx.doi.org/10.31788/RJC.2020.1335692

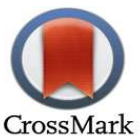


RASĀYAN J. Chem.

Vol. 13 | No. 3 |1555-1570| July - September | 2020

Mammalian aurora kinases comprise a small family of three closely related Serine/Threonine protein kinase namely Aurora A, B and $\mathrm{C}^{14}$. Aurora-A is localized at the centrosome from the time of the duplication through to mitotic exit and regulates chromosomes functions ${ }^{15}$ while Aurora $\mathrm{B}$ is a chromosome passenger protein kinase that regulates Chromosome segregation, chromosome separation, and cytokinesis. ${ }^{16}$ Aurora $\mathrm{C}$ is normally located in germ cells, which can be overexpressed in a high percentage of primary colorectal cancers and variety of tumor cell lines. ${ }^{17}$

An over expressions of Aurora-A in high-grade prostatic intraepithelial neoplasia lesions have been detected, the relationship between Aurora kinase expressions in human prostate cancer. ${ }^{16}$ Aurora A gene occurs in as many as $12-50 \%$ ovarian, gastric, breast, and colorectal cancers. ${ }^{18}$ Many heterocyclic compounds such as pyrazoles are found to be aurora kinase inhibitor. ${ }^{14}$ and CDK1 inhibitor. ${ }^{9}$ Pyrazolo[3,4d]pyrimidine is iso-stere to purine nucleus and hence exhibits promising activity by acting as an ATP inhibitor for the many kinase enzymes such as $\mathrm{CDK} 1^{8,19,20}$ and Aurora kinase inhibitor. ${ }^{20}$ Pyrazolo[3,4b]pyridines were also reported as tyrosine kinase inhibitor ${ }^{21}$ in literature.

The pyrimidine and pyrazole ring containing VX-680 (MK-0457) (Fig.-1) are an aurora kinase inhibitor and also preclinical studied on the patient suffering from chronic myeloid leukemia have shown encouraging results. ${ }^{17,22}$

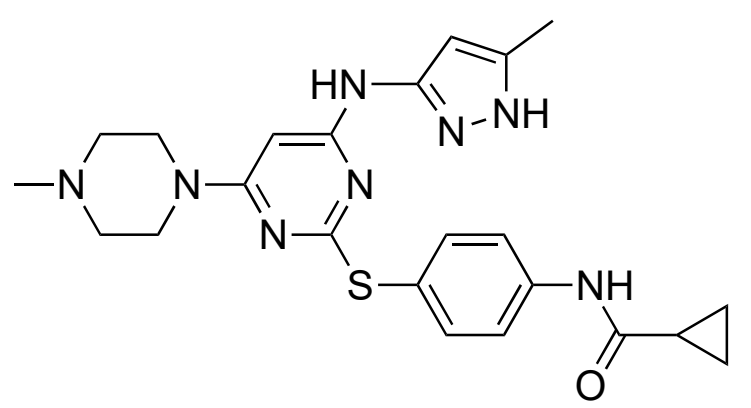

Fig-1: VX-680 (MK-0457)

Receptor tyrosine kinases play an important role in signal transduction pathways that control differentiation and cell division. ${ }^{23}$ An overexpression of tyrosine kinase includes chronic myeloid leukaemia, breast cancer, renal cell carcinoma (RCC), gastrointestinal stomal tumor (GIST), and colon carcinoma. ${ }^{24-27}$

The molecular consequences of the $(9 ; 22)$ translocations are to fuse the ABL tyrosine kinase gene from chromosome 9 to the breakpoint cluster region (BCR) gene on chromosome 22. This BCR-ABL oncogenic tyrosine kinase triggers chronic myeloid leukemia. ${ }^{26}$ In tyrosine kinase family, human epidermal growth factor (HER) overexpression causes breast cancer. ${ }^{27}$

The heterocyclic scaffolds are found to be excellent drug intermediate in the literature. ${ }^{28-31}$ The synthesis of pyrazole derivatives is of great interest in pharmaceutical industries due to their wide range of antiviral, antifungal, anti-inflammatory and anticancer bioactivity. ${ }^{28}$ Among all of the heterocyclic compounds, nonfused pyrazoles give good pharmacological activities such as anti-HIV ${ }^{32}$, antibacterial ${ }^{30}$, analgesic, antiinflammatory ${ }^{31}$ and antimalarial. ${ }^{33}$ Pyrazole fused pyrimidine showed biological activities such as antiviral ${ }^{34}$ antimicrobial ${ }^{35}$, Antibacterial ${ }^{36}$ and anticancer activity. ${ }^{37}$

Many synthetic methods are available for the synthesis of pyrazole derivatives with the catalyst such as palladium ${ }^{38}$, copper ${ }^{39}$, ionic liquid C3[min] $22[\mathrm{Br}]^{-40}$ and triethyl amine ${ }^{41}$ The majority of the synthesis strategies mentioned in the literature survey involve multistep synthesis or expensive catalysts, anhydrous conditions, inert atmosphere, prolonged reaction times, and difficult workup. In continuation of our work on the fused pyrimidines we have synthesized the small heterocyclic molecules, Pyrazolo[3,4d]pyrimidines with very simple and efficient synthetic strategies. ${ }^{42}$

In the present work, the small molecules were designed to fix in small cavities of the protein molecule. The various functional groups such as ketone, thione, amine, nitrile, methyl, phenyl, thiol and hydroxyl groups were incorporated for better interactions. All the designed compounds (Structure is shown in Fig.-8.) were virtually studied on the crystal structures hck, aurora kinase A and anaplastic lymphoma kinase. The good binding scores and interactions on molecular docking prompted us to synthesize a new series of pyrazoles via reaction of salicylaldehyde, malononitrile and hydrazine hydrate at room temperature by grinding in 2 
RASĀYAN J. Chem.

Vol. 13 | No. 3 |1555-1570| July - September | 2020

minutes without solvent and catalyst. The synthesized compounds were screened for their anticancer activity determined by using MTT Assay method ${ }^{43}$ against three different cell lines of K562, A549 and MCF-7. The synthesized compounds were also screened for their antimicrobial activity against seven species.

\section{EXPERIMENTAL}

\section{General}

The Reagents and solvent were purchased from Sigma Aldrich and Merck. The reagents were used without further purification. Melting points were determined by the open capillary method and are uncorrected. ${ }^{1} \mathrm{H}$ NMR was recorded on BRUKER AVANCE II $400 \mathrm{MHz}$. IR spectra were recorded on Perkin Elmer RX I. Mass spectra were documented on waters Q-TOF of micromass spectrometer by electron spray ionization. The compound A was obtained in a solvent-free and catalyst-free condition by grinding of an equal mole of salicylaldehyde, malononitrile and hydrazine hydrate. (Fig.-2) The multi-component reaction was carried out by grinding without solvent as well as in the organic solvents to compare the efficiency of the grinding process and their results are summarized in Table-9. The grinding process was not commonly known to synthesize organic molecules.

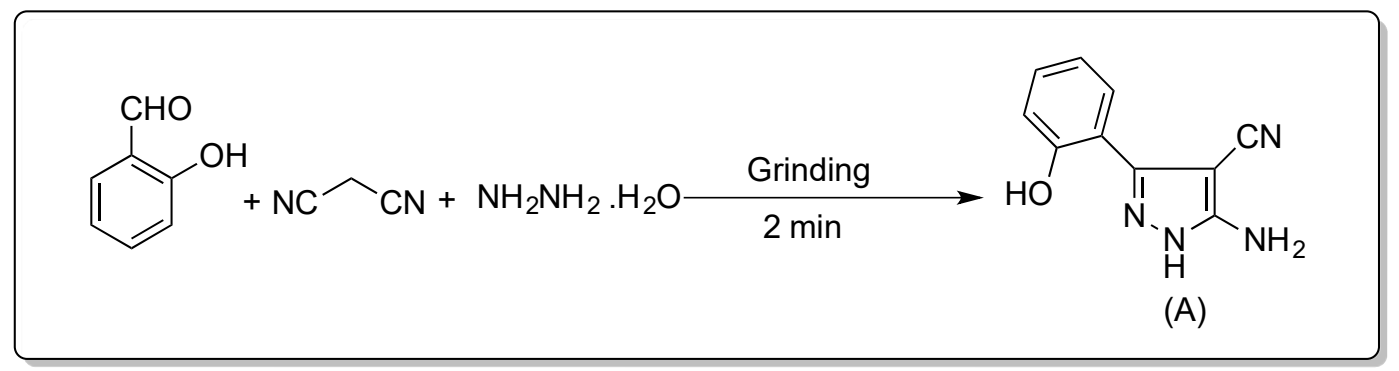

Fig.-2: Scheme-1

The solvent-free and catalyst-free reaction was performed at room temperature within just 2 minutes. The reaction was monitored by TLC (3:2, methanol: water).

The initial experiment was undertaken in the presence of organic solvents such as water and methanol at $60-70{ }^{\circ} \mathrm{C}$ and room temperature also. (Table-1) The reaction at room temperature did not give the final product while on increasing temperature to $70{ }^{\circ} \mathrm{C}$ the desired product was obtained in high yield. The reaction proceeded in dimethyl formamide solvent at $120{ }^{\circ} \mathrm{C}$ but it did not give the desired yield. The product obtained from an equal amount mixture of water and methanol to give the crystalline product with a better yield. The equal mole of 3 compounds was poured into mortar-pestle and ground for just 2 minutes. The yellow powder appeared after 2 min of the reaction process.

Table-1: Optimization Table (A)

\begin{tabular}{c|c|c|c|c|c|c}
\hline Entry & Solvents & Time & Method & Catalyst & Temperature $\left({ }^{\circ} \mathrm{C}\right)$ & $\%$ Yield \\
\hline 1 & Water & 2 hour & Stirring & - & Room temperature & - \\
\hline 2 & Methanol & 2 hour & Stirring & - & Room temperature & - \\
\hline 3 & Water & $20 \mathrm{~min}$ & Stirring & - & 60 & - \\
\hline 4 & Methanol & $20 \mathrm{~min}$ & Stirring & - & 70 & $40 \%$ \\
\hline 5 & $\begin{array}{c}\text { Water + methanol } \\
(1: 1)\end{array}$ & $30 \mathrm{~min}$ & Stirring & - & 120 & $75 \%$ \\
\hline 6 & $\begin{array}{c}\text { Dimethyl } \\
\text { formamide }\end{array}$ & $10 \mathrm{~min}$ & Reflux & - & $26 \%$ \\
\hline 7 & - & $2 \mathrm{~min}$ & Grinding & - & Room temperature & $86 \%$ \\
\hline 8 & - & $2 \mathrm{~min}$ & Grinding, & NaOH & Room temperature & $84 \%$ \\
\hline 9 & - & $5 \mathrm{~min}$ & Grinding & $\begin{array}{c}\text { Triethyl } \\
\text { amine }\end{array}$ & Room temperature & $85 \%$ \\
\hline
\end{tabular}

The grinding process was completed with pure compound and high yield of $86 \%$. The grinding process was carried out without solvent and in the presence of catalysts also but it did not increase the yield. The 
RASĀYAN J. Chem.

Vol. 13 | No. 3 |1555-1570| July - September | 2020

subsequent conditions and optimized experiments revealed that $30 \mathrm{~min}$ and $70{ }^{\circ} \mathrm{C}$ temperature was necessary for the solvent-based reaction condition and the grinding process did not require solvent or catalyst. In the comparison of all reaction conditions, we found a very straightforward and efficient grinding process.

The appearance of a peak at 3459 and $3328 \mathrm{~cm}^{-1}$ in IR spectra showed the presence of $-\mathrm{OH}$ and $-\mathrm{NH}_{2}$ group. The aromatic ring showed peaks at $3059,3029 \mathrm{~cm}^{-1}$. The peak at $2925 \mathrm{~cm}^{-1}$ appeared due to $-\mathrm{CH}$ attached to a ketone group. The peaks at 3059,3029 and $2925 \mathrm{~cm}^{-1}$ proved the formation of keto-enol tautomer in pyrazole. The IR spectra showed a sharp peak in $2359 \mathrm{~cm}^{-1}$ confirmed the presence of $-\mathrm{CN}$ group. The absorption peak at $1598 \mathrm{~cm}^{-1}$ indicates the presence of $-\mathrm{C}=\mathrm{N}$ bond in pyrazole. Its ${ }^{1} \mathrm{H}$ NMR spectrum showed singlet peak at 3.45 and $6.69 \mathrm{ppm}$ confirmed the presence of $\mathrm{NH}_{2}$ and $-\mathrm{OH}$ group respectively. The $-\mathrm{NH}$ group of pyrazole ring showed a singlet peak at $8.97 \mathrm{ppm}$. An aromatic ring showed multiplate at 7.1-7.5 ppm.

The compound $A$ undergoes cyclization to afford new pyrazole fused pyrimidines, $\left(A_{1}-A_{12}\right)$ when reacted with urea, thiourea, guanidine, formic acid, acetic acid, thioglycolic acid, 4-hydroxy benzoic acid, benzoyl chloride and chloroacetyl chloride.

The compounds $A_{1}, A_{2}$ and $A_{3}$ were obtained without catalyst by solid fusion. (Scheme-2) The Compound "A" was fused with Urea, thiourea, and guanidine carbonate in several conditions such as reflux and solid fusion to yield $A_{1}, A_{2}$ and $A_{3}$ respectively. Both conditions were applied with catalyst and in the absence of a catalyst. The results are given in Table-2. The reaction was carried out at different temperatures and solvent in which Sodium methoxide, triethyl amine did not give the desired product. The optimized overall results discovered that the solid fusion reaction was the best way to synthesize pyrazolopyrimidones/thiones that did not require any catalyst and can be easily carried without any solvent.

The absorption in IR spectra at 3440 and $3349 \mathrm{~cm}^{-1}$ confirmed the presence of $-\mathrm{OH}$ and $-\mathrm{NH}_{2}$ groups respectively. The removal of the absorption peak of $-\mathrm{CN}$ at $2359 \mathrm{~cm}^{-1}$ confirmed the cyclization reaction. Its ${ }^{1} \mathrm{H}$ NMR spectrum showed the singlet peak at 3.35 and 8.09 of $-\mathrm{NH}_{2}$ and $-\mathrm{OH}$ respectively. The upfield shift of $-\mathrm{NH}_{2}$ group peak from 3.45 to $3.35 \mathrm{ppm}$ confirmed the formation of a new $-\mathrm{NH}_{2}$ group. The $-\mathrm{NH}$ group of pyrazole showed a downfield shift at $11.15 \mathrm{ppm}$ due to the fused pyrimidine ring. The appearance of a new singlet peak at $8.90 \mathrm{ppm}$ confirmed the presence of $-\mathrm{NH}$ of the pyrimidine ring. The MASS spectrometry confirmed the compound $A_{1}$ by an appearance of molecular ion peak value at $\mathrm{m} / \mathrm{z} 243.27$. The fusion with guanidine and thiourea was also confirmed by spectral analysis.

Table-2: Optimization Table $\left(\mathrm{A}_{1}, \mathrm{~A}_{2}, \mathrm{~A}_{3}\right)$

\begin{tabular}{c|c|c|c|c|c}
\hline No & Solvents & Catalyst & $\begin{array}{c}\text { Temperature } \\
\left({ }^{\circ} \mathrm{C}\right)\end{array}$ & $\begin{array}{c}\text { Time } \\
(\text { Hour })\end{array}$ & $\%$ Yield \\
\hline 1 & Methanol & Sodium methoxide & 70 & 6 & - \\
\hline 2 & Methanol & Triethyl amine & 70 & 6 & - \\
\hline 3 & Dichloro methane & Tiethyl amine & 35 & 8 & - \\
\hline 4 & Dimethyl formamide & Triethyl amine & 150 & 5 & - \\
\hline 5 & Dimethyl formamide & Sodium methoxide & 150 & 8 & $19 \%$ \\
\hline 6 & - & - & 120 & 6 & $35 \%$ \\
\hline 7 & - & - & 160 & 1 & $27 \%$ \\
\hline 8 & - & - & 160 & 2 & $55-65 \%$ \\
\hline 9 & - & Triethyl amine & 160 & 2 & $52 \%$ \\
\hline 10 & - & $\mathrm{K}_{2} \mathrm{CO}_{3}$ & 160 & 2 & $50 \%$ \\
\hline 11 & - & Sodium methoxide & 160 & 2 & $54 \%$ \\
\hline
\end{tabular}

The compound A' was synthesized from compound A by adding it to Conc. $\mathrm{H}_{2} \mathrm{SO}_{4}$ at $0-5{ }^{\circ} \mathrm{C}$ with stirring. The mixture was poured to ice-cold water and sodium bicarbonate was added to it till neutralization. The yellow product was filtered and washed with ice-cold water. (Scheme-3)

The compound A' was cyclized with formic acid, acetic acid, thioglycolic acid and 4-hydroxy benzoic acid to form $A_{4}, A_{5}, A_{6}$ and $A_{11}$ respectively. (Scheme-4) The compounds $A_{4}$ and $A_{5}$ were prepared without solvent in presence of the $1 \mathrm{ml} \mathrm{H}_{2} \mathrm{SO}_{4}$ under reflux condition for $4-5$ hours. The synthesis took 8 hours if the compounds were directly synthesized from compound A. The removal of a peak at $2359,3440,3349$ 
RASĀYAN J. Chem.

Vol. 13 | No. 3 |1555-1570| July - September | 2020

$\mathrm{cm}^{-1}$ and absorption peak at $1712 \mathrm{~cm}^{-1}$ in IR spectra confirmed the cyclisation reaction in $\mathrm{A}_{5}$. Its ${ }^{1} \mathrm{H}$ NMR spectra showed the disappearance of $-\mathrm{NH}_{2}$ peak and the appearance of the peak at $2.54 \mathrm{ppm}$ confirmed the presence of $-\mathrm{CH}_{3}$ group.

The compound A' and Chloroacetyl chloride was stirred at $0-5^{\circ} \mathrm{C}$ in the presence of catalyst triethyl amine for $15 \mathrm{~min}$. After stirring the mixture was refluxed till the completion of the reaction to obtain compound A 7. (Scheme-5) The reaction was refluxed in diverse solvents such as methanol, dimethyl formamide, dichloro methane but the reaction gave the desired product only in dimethyl formamide (Table-3).

The absorption peak found at $2974 \mathrm{~cm}^{-1}$ confirmed the presence of $-\mathrm{CH}_{2}$ group. The appearance of a sharp peak at $751 \mathrm{~cm}^{-1}$ in IR spectroscopy indicated the presence of $-\mathrm{Cl}$ in compound $\mathrm{A}_{7}$. The Peak at $1689 \mathrm{~cm}^{-1}$ confirmed the presence of the ketone group.

Compound $\mathrm{A}_{9}$ was synthesized from benzoyl chloride under reflux condition without a catalyst. (Scheme: 6) The reaction was undertaken in different solvents such as dichloromethane, dimethyl formamide and dioxane. The optimized results showed that dimethyl formamide required for the reaction as the other solvents did not give the final product. The Disappearance of a peak at $2359 \mathrm{~cm}^{-1}$ and $3328 \mathrm{~cm}^{-1}$ peaks confirmed the completion of the reaction. The ${ }^{1} \mathrm{H}$ NMR spectra showed the peak of $-\mathrm{CH}$ at $2.53 \mathrm{ppm}$ confirmed the compound.

\begin{tabular}{|c|c|c|c|c|c|}
\hline No & Solvents & Catalyst & $\begin{array}{c}\text { Temperature } \\
\left({ }^{\circ} \mathrm{C}\right)\end{array}$ & $\begin{array}{l}\text { Time } \\
\text { (Hour) }\end{array}$ & $\%$ Yield \\
\hline 1 & Methanol & - & 70 & 5 & - \\
\hline 2 & Methanol & Triethyl amine & 70 & 7 & - \\
\hline 3 & $\begin{array}{l}\text { Dichloro } \\
\text { methane }\end{array}$ & Triethyl amine & 30 & 8 & - \\
\hline 4 & $\begin{array}{c}\text { Dimethyl } \\
\text { formamide }\end{array}$ & - & 150 & 7 & $57 \%$ \\
\hline 5 & $\begin{array}{c}\text { Dimethyl } \\
\text { formamide }\end{array}$ & Triethyl amine & 150 & 5 & $68 \%$ \\
\hline
\end{tabular}

\section{Synthesis of Compound A: (5-amino-3-(2-hydroxyphenyl)-1H-pyrazole-4-carbonitrile)}

Salicylaldehyde $(0.01 \mathrm{~mol})$ and malononitrile $(0.01)$ were taken in a mortar and the resulting mixture was grind for 1 minute. Hydrazine hydrate $(0.01 \mathrm{~mol})$ was added to the mixture by continuous grinding for 2 minutes. The Reaction was supervised by TLC (2:3, water: methanol). A Yellow solid appeared after completion of the reaction. The product was isolated and washed with hot water. The product was crystallized from aqueous methanol to yield a pure crystalline product.

A: Yellow powder; Yield: $87 \%$; M.P. $=168^{\circ} \mathrm{C}$; UV $(\lambda \max )(\mathrm{nm}): 230,248,297,359$; $\mathrm{IR}(\mathrm{KBr}) \mathrm{cm}^{-1}=$ 3459(-OH), 3328( $\left(\mathrm{NH}_{2}\right), 3059,3029(\mathrm{Ar}-\mathrm{H}), 2925(-\mathrm{CH}=\mathrm{CO}-), 2359(-\mathrm{CN}), 2336(=\mathrm{C}-\mathrm{H}), 1598(-\mathrm{C}=\mathrm{N}) ;{ }^{1} \mathrm{H}$ NMR: $\delta$ ppm: $3.45\left(\mathrm{~s}, 2 \mathrm{H}, \mathrm{NH}_{2}\right), 6.69(\mathrm{~s}, 1 \mathrm{H}, \mathrm{OH}), 8.97(\mathrm{~s}, 1 \mathrm{H},-\mathrm{NH}), 4.58(\mathrm{~d}, 1 \mathrm{H},-\underline{\mathrm{CH}}-\mathrm{C}(\mathrm{OH})), 5.07$ (d, $1 \mathrm{H},-\mathrm{CH}), 7.1-7.5$ (m, Ar-H); MS m/z (\%): $\mathrm{M}^{+}=200, \mathrm{M}+1=201$

Synthesis of Compound ( $\left.A_{1}, A_{2}\right)$ : 4-amino-3-(2-hydroxyphenyl)-1,7-dihydro-6H-pyrazolo[3,4d]pyrimidin-6-one (or thione) and $\left(A_{3}\right)$ 2-(4-amino-6-imino-6,7-dihydro-1H-pyrazolo[3,4d]pyrimidin-3-yl)phenol

A mixture of Pyrazole (A) $(0.01 \mathrm{~mol})$ and Urea $(0.01 \mathrm{~mol})$ was fused in an oil bath at $160{ }^{\circ} \mathrm{C}$ for 2 hours. The Reactions were monitored with TLC. (3:2, ethyl acetate: n-hexane) After cooling and washed with methanol $(25 \mathrm{ml})$, the brown solid was filtered off and recrystallized with 1:1 mixture of Dimethyl formamide and methanol to obtain pure yield. The compounds $A_{2}$ and $A_{3}$ were synthesized by a similar method using thiourea and Guanidine carbonate respectively.

$\mathbf{A}_{1}$ : Brown powder; Yield: $57 \%$; M.P. $=218^{\circ} \mathrm{C}$; UV $(\lambda \max )(\mathrm{nm}): 242,292,353 ; \mathrm{IR}(\mathrm{KBr}) \mathrm{cm}^{-1}=3440(-$ $\mathrm{OH}), 3349\left(\mathrm{NH}_{2}\right), 3192(\mathrm{Ar}-\mathrm{H}), 1714(-\mathrm{C}=\mathrm{O}), 1620\left(2^{\circ} \mathrm{NH}\right), 1557(-\mathrm{C}=\mathrm{N}) ;{ }^{1} \mathrm{H}$ NMR: $\delta$ ppm: $3.36(\mathrm{~s}, 2 \mathrm{H}$, 
RASĀYAN J. Chem.

Vol. 13 | No. 3 |1555-1570| July - September | 2020

$\left.\mathrm{NH}_{2}\right), 7.95,8.09$ (s, 1H, OH), $8.90(\mathrm{~s}, 1 \mathrm{H},-\mathrm{NH}$, pyrimidine) 11.15 (s, 1H, -NH, pyrazole), 6.85-7.58 (m, $\mathrm{Ar}-\mathrm{H}) ; \mathrm{MS} \mathrm{m} / \mathrm{z}(\%): \mathrm{M}-1=242, \mathrm{M}-2=241$

A2: Brown powder; Yield: $62 \%$; M.P. $=188^{\circ} \mathrm{C}$; UV $(\lambda \max )(\mathrm{nm}): 247,272,297,315,333$; IR $(\mathrm{KBr}) \mathrm{cm}^{-}$ ${ }^{1}=3441(-\mathrm{OH}), 3349\left(\mathrm{NH}_{2}\right), 3239(\mathrm{Ar}-\mathrm{H}), 1606\left(2^{\circ} \mathrm{NH}\right), 1556(-\mathrm{C}=\mathrm{N}), 1110(\mathrm{C}=\mathrm{S}) ;{ }^{1} \mathrm{H}$ NMR: $\delta$ ppm:3.35 (s, $\left.2 \mathrm{H}, \mathrm{NH}_{2}\right), 7.92,8.10$ (s, 1H, OH), 8.89 (s, 1H, -NHpyrimidine), 11.13 (s, 1H, -NHpyrazole) $), 6.82-7.56$ (m, Ar-H); MS m/z (\%): M+1 = 259, M+2=260

$\mathbf{A}_{3}$ : Brown powder; Yield: $67 \%$; M.P. $=210{ }^{\circ} \mathrm{C}$; IR $(\mathrm{KBr}) \mathrm{cm}^{-1}=4670(-\mathrm{OH}), 3346\left(\mathrm{NH}_{2}\right), 3187(\mathrm{Ar}-\mathrm{H})$, $1620(=\mathrm{NH}), 1557(-\mathrm{C}=\mathrm{N}) ;{ }^{1} \mathrm{H}$ NMR: $\delta$ ppm: $3.36\left(\mathrm{~s}, 2 \mathrm{H}, \mathrm{NH}_{2}\right), 7.95,8.17(\mathrm{~s}, 1 \mathrm{H}, \mathrm{OH}), 8.95(\mathrm{~s}, 1 \mathrm{H},-\mathrm{NH}$, pyrimidine), $11.18(\mathrm{~s}, 1 \mathrm{H},-\mathrm{NH}$, pyrazole $), 6.82-7.63(\mathrm{~m}, \mathrm{Ar}-\mathrm{H}) ; \mathrm{MS} \mathrm{m} / \mathrm{z}(\%): \mathrm{M}^{+}=242, \mathrm{M}+1=243, \mathrm{M}+2$ $=243$

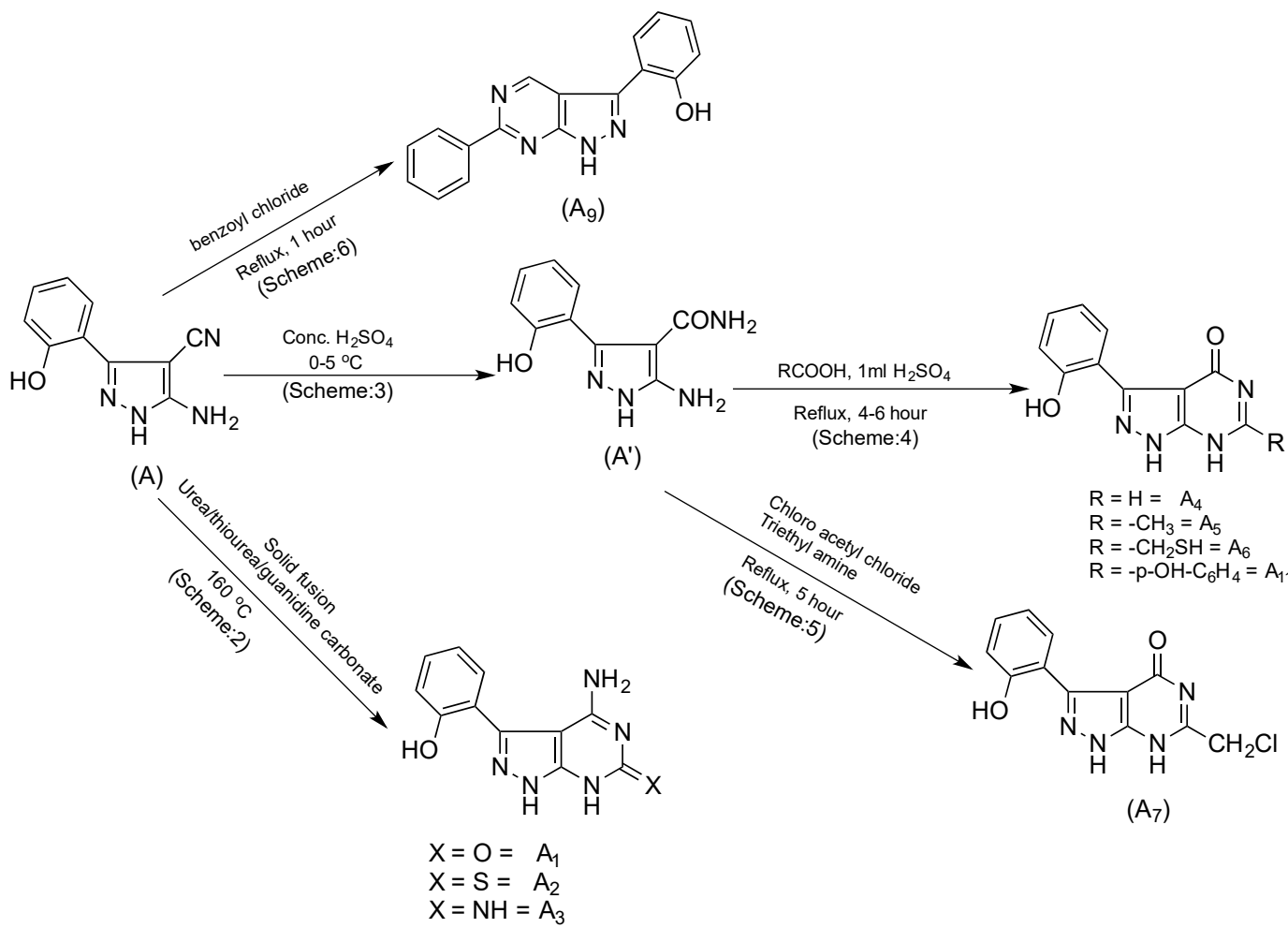

Fig.-3: Reaction Schemes

Synthesis of Compound $\mathrm{A}_{4}$ (3-(2-hydroxyphenyl)-1,7-dihydro-4H-pyrazolo[3,4-d]pyrimidin-4-one), A (3-(2-hydroxyphenyl)-6-methyl-1,7-dihydro-4H-pyrazolo[3,4-d]pyrimidin-4-one)

A mixture of Amide derivative of pyrazole (A') $(0.0045 \mathrm{~mol})$, formic acid $(15 \mathrm{ml})$ and $1 \mathrm{ml} \mathrm{Conc} . \mathrm{H}_{2} \mathrm{SO}_{4}$ was refluxed in a sand bath for $4-5$ hours. The reaction was monitored with TLC (3:2, water: methanol). The reaction was cooled after completion and poured into ice-cooled water. Neutralized the resulting mixture by addition of dilute $\mathrm{NaOH}$ solution. The resulting solid was washed with cold water and recrystallized with $1: 1$ of Acetone: water to obtain a pure crystalline product. The compound $\mathrm{A}_{5}$ was synthesized by a similar method using acetic acid.

A4: Orange powder; Yield: $71 \%$; M.P. $=158^{\circ} \mathrm{C}$; UV $(\lambda \max )(\mathrm{nm}): 247,298,314,325,367$; IR $(\mathrm{KBr}) \mathrm{cm}^{-}$ ${ }^{1}=3447(-\mathrm{OH}), 3216(\mathrm{NH}), 3046(\mathrm{Ar}-\mathrm{H}), 1728(-\mathrm{C}=\mathrm{O}), 1620(=\mathrm{NH}), 1560(-\mathrm{C}=\mathrm{N})$

A5: Brown powder; yield: $92 \%$; M.P $=206^{\circ} \mathrm{C}$; UV $(\lambda \max )(\mathrm{nm}): 230,296,344$; IR $(\mathrm{KBr}) \mathrm{cm}^{-1}=3381(-$ $\mathrm{OH}), 3162\left(\mathrm{NH}_{2}\right), 3059(\mathrm{Ar}-\mathrm{H}), 1754,1712(-\mathrm{C}=\mathrm{O}), 1679,1621(\mathrm{NH}), 1567(-\mathrm{C}=\mathrm{N}) ;{ }^{1} \mathrm{H}$ NMR: $\delta$ ppm: 3.29 
RASĀYAN J. Chem.

Vol. 13 | No. 3 |1555-1570| July - September | 2020

$\left(\mathrm{s}, 2 \mathrm{H}, \mathrm{NH}_{2}\right), 2.54\left(\mathrm{~s}, 3 \mathrm{H},-\mathrm{CH}_{3}\right), 8.04(\mathrm{~s}, 1 \mathrm{H}, \mathrm{OH}), 8.91(\mathrm{~s}, 1 \mathrm{H},-\mathrm{NH}$ pyrimidine $), 11.18(\mathrm{~s}, 1 \mathrm{H},-$ NHpyrazole), 6.93-7.57 (m, Ar-H); MS m/z (\%): M-1 = 242, M-2 = 241

Synthesis of $\left(A_{6}\right)$ (3-(2-hydroxyphenyl)-6-(mercaptomethyl)-1,7-dihydro-4H-pyrazolo[3,4d]pyrimidin-4-one) and $A_{11}$ (3-(2-hydroxyphenyl)-6-(4-hydroxyphenyl)-1,7-dihydro-4Hpyrazolo[3,4-d]pyrimidin-4-one)

The compounds, Amide derivative of pyrazole (A') $(0.01 \mathrm{~mol})$, thioglycolic acid $(0.01 \mathrm{~mol})$ and $0.5 \mathrm{ml}$ Conc. $\mathrm{H}_{2} \mathrm{SO}_{4}$ were mixed in $8 \mathrm{ml}$ of dimethyl formamide. Afterward, the mixture was refluxed in the sand bath for 2 hours. The reaction progress was observed with TLC. (3:2, ethyl acetate:hexane). Upon completion of the reaction, the reaction mixture was cooled to room temperature and decanted to the icecooled water. The resulting product was filtered and washed with water. The product was purified from charcoal and recrystallized from the mixture of 1:1 (dimethyl formamide: water). The compound $A_{11}$ was synthesized by a similar method using 4-hydroxy benzoic acid.

A6: Yellow powder; Yield: $87 \%$; M.P. $=144^{\circ} \mathrm{C}$; UV $(\lambda \max )(\mathrm{nm}): 274,296,313$; IR $(\mathrm{KBr}) \mathrm{cm}^{-1}=3396(-$ $\mathrm{OH}), 3241\left(-\mathrm{NH}_{2}\right), 3067(\mathrm{Ar}-\mathrm{H}), 2955\left(-\mathrm{CH}_{2} \mathrm{SH}\right), 1692(-\mathrm{C}=\mathrm{O}), 1620(-\mathrm{C}=\mathrm{N}), 2635(-\mathrm{SH}) ;{ }^{1} \mathrm{H}$ NMR: $\delta$ ppm: $3.31\left(\mathrm{~s}, 2 \mathrm{H}, \mathrm{NH}_{2}\right), 2.53\left(\mathrm{~s}, 2 \mathrm{H}, \mathrm{CH}_{2}\right), 11.16(\mathrm{~s}, 1 \mathrm{H},-\mathrm{NH}$, pyrazole $), 7.80(\mathrm{~s}, 1 \mathrm{H}, \mathrm{OH}), 8.92(\mathrm{~s}, 1 \mathrm{H},-$ $\mathrm{NH})$, 6.7-7.4 (m, Ar-H); MS m/z (\%): $\mathrm{M}^{+}=274 \mathrm{M}+1=275$

Synthesis of $\left(\mathrm{A}_{7}\right)$ (6-(chloromethyl)-3-(2-hydroxyphenyl)-3,7-dihydro-4H-pyrazolo[3,4-d]pyrimidin4-one

The compound A' $(0.01 \mathrm{~mol})$ was dissolved in $10 \mathrm{ml}$ of Dimethyl formamide and Chloro acetyl chloride $(0.01 \mathrm{~mol})$ was added to the solution with stirring at $0-5{ }^{\circ} \mathrm{C}$. The solution was stirred for $15-20 \mathrm{~min}$ and refluxed for 5 hours. The reaction mixture was cooled and poured into the water. The resulting product was filtered and washed with water. The product was purified with Dimethyl formamide: water $(7: 3)$ and charcoal.

A 7 : Brown powder; Yield: $68 \%$; M.P. $=208^{\circ} \mathrm{C}$; UV $(\lambda \max )(\mathrm{nm}): 227,294,355$; IR $(\mathrm{KBr}) \mathrm{cm}^{-1}=3680(-$ $\mathrm{OH}), 3046(\mathrm{Ar}-\mathrm{H}), 2974\left(-\mathrm{CH}_{2}\right), 751(\mathrm{C}-\mathrm{Cl}), 1689(-\mathrm{C}=\mathrm{O}), 1575(-\mathrm{C}=\mathrm{N}) ;{ }^{1} \mathrm{H}$ NMR: $\delta$ ppm: $3.29(\mathrm{~s}, 2 \mathrm{H}$, $\left.\mathrm{NH}_{2}\right), 2.52\left(\mathrm{~s}, 2 \mathrm{H},-\mathrm{CH}_{2}\right), 11.15(\mathrm{~s}, 1 \mathrm{H}, \mathrm{NH}$ pyrazole $), 8.95$ (s, $1 \mathrm{H}, \mathrm{NH}$ pyrimidine), 6.95-7.62 (m, Ar-H); $\mathrm{MS} \mathrm{m} / \mathrm{z}(\%): \mathrm{M}+1=277$

Synthesis of (A9) 2-(6-phenyl-1H-pyrazolo[3,4-d]pyrimidin-3-yl)phenol

The mixture of compound A $(0.01 \mathrm{~mol})$ and benzoyl chloride $(5 \mathrm{ml})$ was refluxed for 1 hour. The brown compound appeared in the R.B.F. The compound was poured into the water and washed with $1 \mathrm{~N} \mathrm{NaOH}$ solution. The residues were filtered and crystallized with Dimethyl formamide: methanol (1:1).

A9: Yellow powder; Yield:70\%; M.P. $=218^{\circ} \mathrm{C}$; UV $(\lambda \max )(\mathrm{nm}): 230,247,312,361 ; \mathrm{IR}(\mathrm{KBr}) \mathrm{cm}^{-1}=$ $3346(-\mathrm{OH}), 3210(\mathrm{Ar}-\mathrm{H}), 2936(-\mathrm{CH}), 1622(-\mathrm{NH}), 1568(-\mathrm{C}=\mathrm{N}) ;{ }^{1} \mathrm{H}$ NMR: $\delta$ ppm: 2.59 (s, 1H, $\left.-\mathrm{CH}\right), 8.12$ (s, 1H, OH), 7.2-7.8 (m, Ar-H); MS m/z (\%): $\mathrm{M}^{+}=288.21, \mathrm{M}+1=289.19$.

\section{Molecular Docking Studies}

\section{RESULTS AND DISCUSSION}

We examined the interaction of some newly designed compounds with Aurora A crystal structure (2BMC.pdb), the crystal structure of hck (1QCF.pdb), Crystal Structure of Anaplastic Lymphoma Kinase (4MKC.pdb). An overexpression of Anaplastic Lymphoma Kinase and hck-src family causes lung carcinoma and chronic myeloid leukemia respectively.

All compounds were studied virtually on the crystal structure of kinases. The molecular docking was performed utilizing vLifeMDS (4.6.04092017). In the molecular docking studies, we found good results of interactions and docking scores (Table- 4).

An excellent binding score was observed in grip docking study of compound $\mathrm{A}_{3}$ with the crystal structure of 1QCF(Fig.-4, Table-5). We found that on the best scoring position of $-68 \mathrm{Kcal} / \mathrm{mol}$. the compound $\mathrm{A}_{3}$ 
RASĀYAN J. Chem.

Vol. 13 | No. 3 |1555-1570| July - September | 2020

was potently bound to the protein via five hydrogen bond interactions and pi-pi stacking. 1C of pyrazole and TRP428 2769C established aromatic interaction with distance $5.19 \AA$.

Table-4: Docking Score of Synthesized Compounds

\begin{tabular}{c|c|c|c|c}
\hline No & Compounds & $\begin{array}{c}\text { Docking Score } \\
(1 \mathrm{QCF}) \\
\text { Kcal/mol }\end{array}$ & $\begin{array}{c}\text { Docking Score } \\
(4 \mathrm{MKC}) \\
\text { Kcal/mol }\end{array}$ & $\begin{array}{c}\text { Docking Score } \\
(2 \mathrm{BMC}) \\
\text { Kcal/mol }\end{array}$ \\
\hline 1 & $\mathrm{~A}$ & - & -50.2 & -38.8 \\
\hline 2 & $\mathrm{~A}_{1}$ & - & - & -46.67 \\
\hline 3 & $\mathrm{~A}_{2}$ & - & -44.90 & -48.23 \\
\hline 4 & $\mathrm{~A}_{3}$ & -68 & -37.6 & -46.28 \\
\hline 5 & $\mathrm{~A}_{4}$ & - & -50.6 & -48.94 \\
\hline 6 & $\mathrm{~A}_{5}$ & - & - & -42.97 \\
\hline 7 & $\mathrm{~A}_{6}$ & - & - & -47.57 \\
\hline 8 & $\mathrm{~A}_{7}$ & - & - & -52.69 \\
\hline 9 & $\mathrm{~A}_{9}$ & -64.39 & -58.45 & -61.81 \\
\hline 10 & $\mathrm{~A}_{11}$ & -64.38 & - & -45.99 \\
\hline
\end{tabular}

The five hydrogen bonds formed by amine and Imine group on pyrimidine and hydroxyl group with ARG388 2467N, ARG388 6097H, ARG388 6099H, ASN391 2478N, ASN391 6111H residues. In this way, the interactions were stabilized by 5 hydrogen bonds. The enzyme interactions with $\mathrm{A}_{3}$ in $2 \mathrm{D}$ view revealed that $\mathrm{A}_{3}$ molecule is well embedded in the 1QCF crystal structure(Table-5).

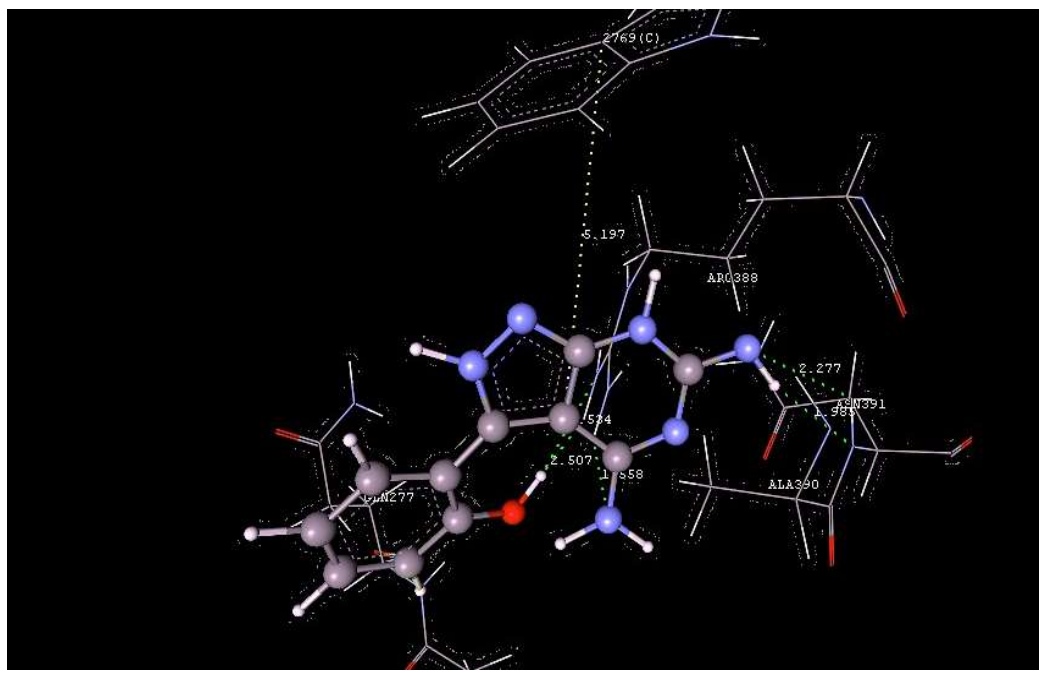

Fig.-4: Predicted Binding Pose of 1QCF with A

Table-5: The Interactions of $1 \mathrm{QCF}$ and $\mathrm{A}_{3}$

\begin{tabular}{c|c|c|c}
\hline Residue Atom & Ligand Atom & Distance & Interaction \\
\hline TRP428 2769C & $1 \mathrm{C}$ & 5.197 & Aromatic Interaction \\
\hline ARG388 2467N & $28 \mathrm{H}$ & 2.534 & Hydrogenbond Interaction \\
\hline ARG388 6097H & $11 \mathrm{~N}$ & 1.558 & Hydrogenbond Interaction \\
\hline ARG388 6099H & $18 \mathrm{O}$ & 2.507 & Hydrogenbond Interaction \\
\hline ASN391 2478N & $23 \mathrm{H}$ & 1.985 & Hydrogenbond Interaction \\
\hline ASN391 6111H & $12 \mathrm{~N}$ & 2.277 & Hydrogenbond Interaction \\
\hline
\end{tabular}

The virtual screening of compound A with 4MKC was studied. The two pi-pi stacking (Aromatic interactions) with the highest docking score of $-50.2 \mathrm{Kcal} / \mathrm{mol}$ (Fig.-5, Table-6).

$-\mathrm{NH}$ of pyrazole bound with TYR1327 1780C with distance 5.063 $\AA$. Benzene ring also showed pi-pi stacking with TYR1327 1780C with distance of $4.243 \AA$. Pyrazole bound in the 4MKC cavity with only two aromatic interactions for good binding. 
RASĀYAN J. Chem.

Vol. 13 | No. 3 |1555-1570| July - September | 2020

The compound $\mathrm{A}_{9}$ showed an excellent binding score of $-61.81 \mathrm{Kcal} / \mathrm{mol}$ with $2 \mathrm{BMC}$. The compound $\mathrm{A}$ exhibited two aromatic interactions of HIS306 9828C, SER342 $12245 \mathrm{O}$ with 10C and 24H with 2BMC respectively. The $-\mathrm{NH}$ of pyrazole gave hydrogen bond interaction with SER342 24866H with distance 2.517 Å. (Fig.-6, Table-7)

The compound $\mathrm{A}_{3}$ also interacted with $2 \mathrm{BMC}$ to give the best binding score of $-46.28 \mathrm{Kcal} / \mathrm{mol}$. (Fig.-7, Table-8) The compound $\mathrm{A}_{3}$ showed 9 hydrogen bond interactions with pyrazole and pyrimidine $-\mathrm{NH}$ group, an imine of pyrimidine ring, a hydroxyl group, amine group of a pyrimidine with residues LYS162 2419N, LYS162 15249H, ARG255 3198N, ARG255 3201N, ARG255 16025H, PHE275 3341N and PHE275 $16176 \mathrm{H}$ respectively.

The compound $\mathrm{A}_{5}$ interacted with $2 \mathrm{BMC}$ at best docking score $-42.97 \mathrm{Kcal} / \mathrm{mol}$, showed 3 hydrophobic interactions of the methyl group with 3 residues of protein (LYS162 2418C, LEU178 2545C and PHE275 $3345 \mathrm{C}$ ) ketone group and $-\mathrm{NH}$ group of pyrimidine ring established hydrogen bond interactions with PHE275 16176H residue 2BMC(Fig.-8, Table-9). Based on our results, we have tested our compounds invitro on human cell lines K-562 (leukaemia), A-549 (lung cancer) and MCF-7 (Breast cancer).

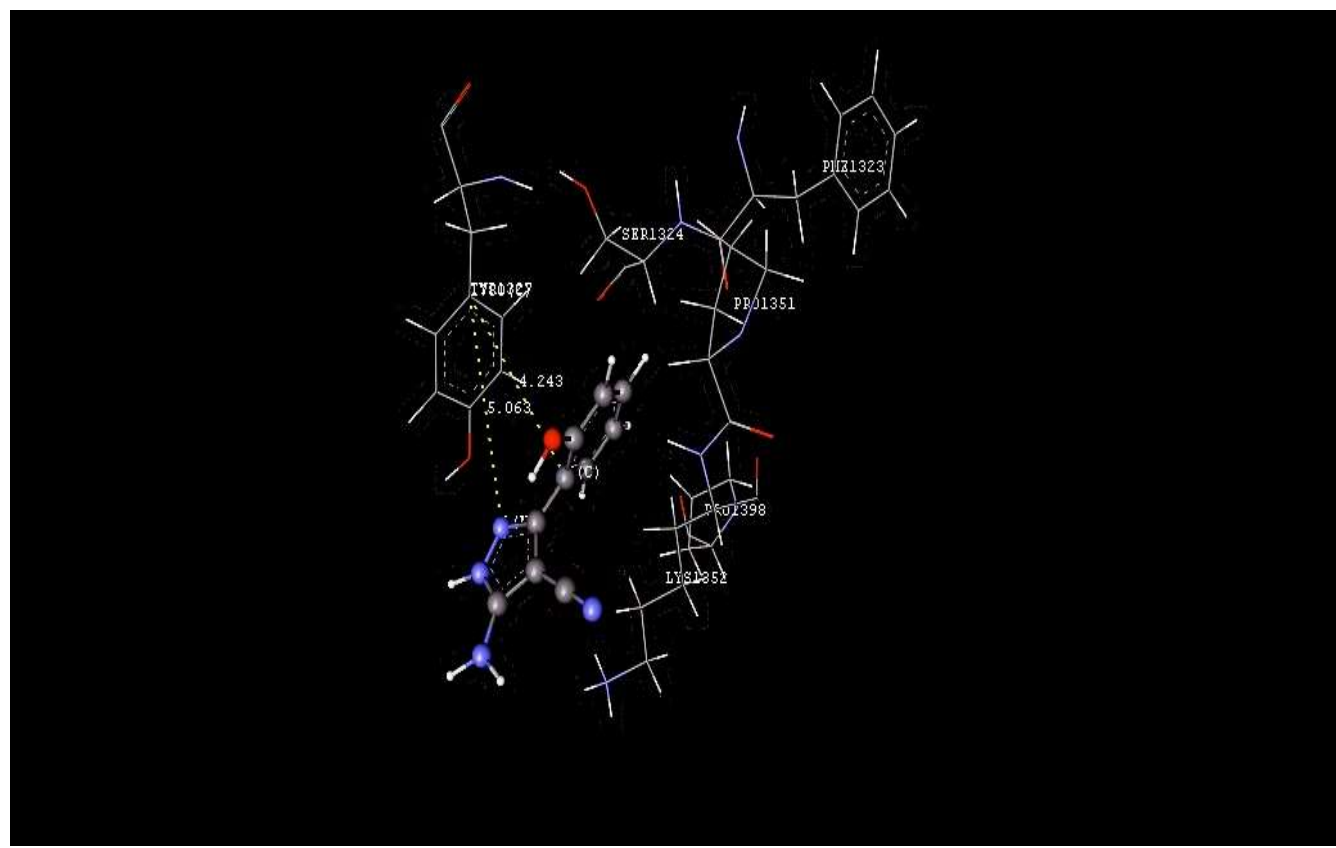

Fig-5: Predicted Binding Pose of 4MKC with A

Table-6: The Interactions of 4MKC and A

\begin{tabular}{c|c|c|c}
\hline Residue Atom & Ligand Atom & Distance & Interaction \\
\hline TYR1327 1780C & $1 \mathrm{~N}$ & 5.063 & Aromatic interaction \\
\hline TYR1327 1780C & $6 \mathrm{C}$ & 4.243 & Aromatic interaction \\
\hline
\end{tabular}

Table-7: The Interactions of $2 \mathrm{BMC}$ and $\mathrm{A}_{9}$

\begin{tabular}{c|c|c|c}
\hline Residue Atom & Ligand Atom & Distance & Interaction \\
\hline HIS306 9828C & $10 \mathrm{C}$ & 5.010 & Aromatic interaction \\
\hline SER342 12245O & $24 \mathrm{H}$ & 2.006 & Aromatic interaction \\
\hline SER342 24866H & $8 \mathrm{~N}$ & 2.517 & Hydrogenbond interaction \\
\hline
\end{tabular}

Table-8: The Interactions of $2 \mathrm{BMC}$ and $\mathrm{A}_{3}$

\begin{tabular}{c|c|c|c}
\hline Residue Atom & Ligand Atom & Distance & Interaction \\
\hline LYS162 2419N & $23 \mathrm{H}$ & 2.404 & Hydrogenbond Interaction \\
\hline LYS162 15249H & $12 \mathrm{~N}$ & 2.525 & Hydrogenbond Interaction \\
\hline ARG255 3198N & $20 \mathrm{H}$ & 2.332 & Hydrogenbond Interaction \\
\hline ARG255 3201N & $20 \mathrm{H}$ & 1.769 & Hydrogenbond Interaction \\
\hline
\end{tabular}

1563 
RASĀYAN J. Chem.

Vol. 13 | No. 3 |1555-1570| July - September | 2020

\begin{tabular}{c|c|c|c}
\hline ARG255 $16025 \mathrm{H}$ & $8 \mathrm{~N}$ & 1.892 & Hydrogenbond Interaction \\
\hline ARG255 16025H & $18 \mathrm{O}$ & 2.461 & Hydrogenbond Interaction \\
\hline PHE275 3341N & $19 \mathrm{H}$ & 1.969 & Hydrogenbond Interaction \\
\hline PHE275 $16176 \mathrm{H}$ & $3 \mathrm{~N}$ & 1.747 & Hydrogenbond Interaction \\
\hline PHE275 16176H & $9 \mathrm{~N}$ & 1.911 & Hydrogenbond Interaction \\
\hline
\end{tabular}

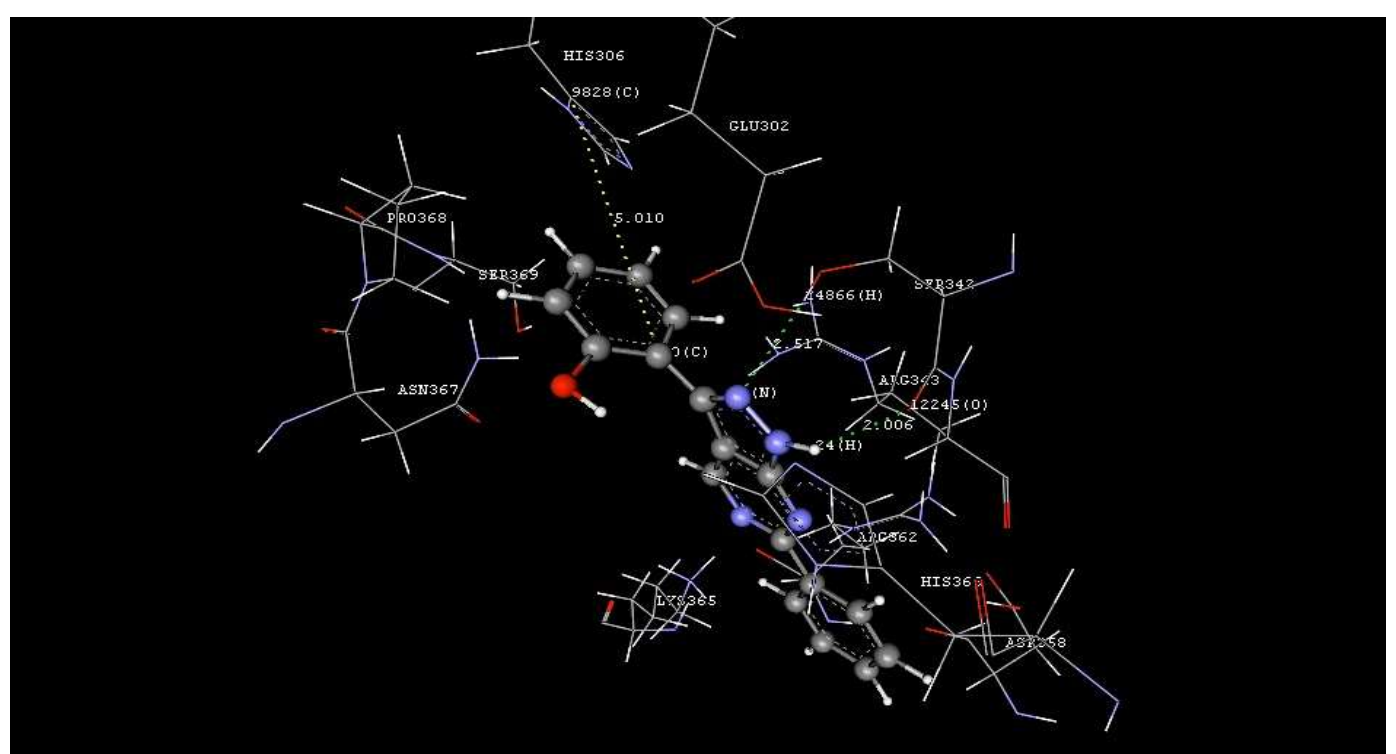

Fig-6: Predicted Binding Pose of 2BMC with $\mathrm{A}_{9}$

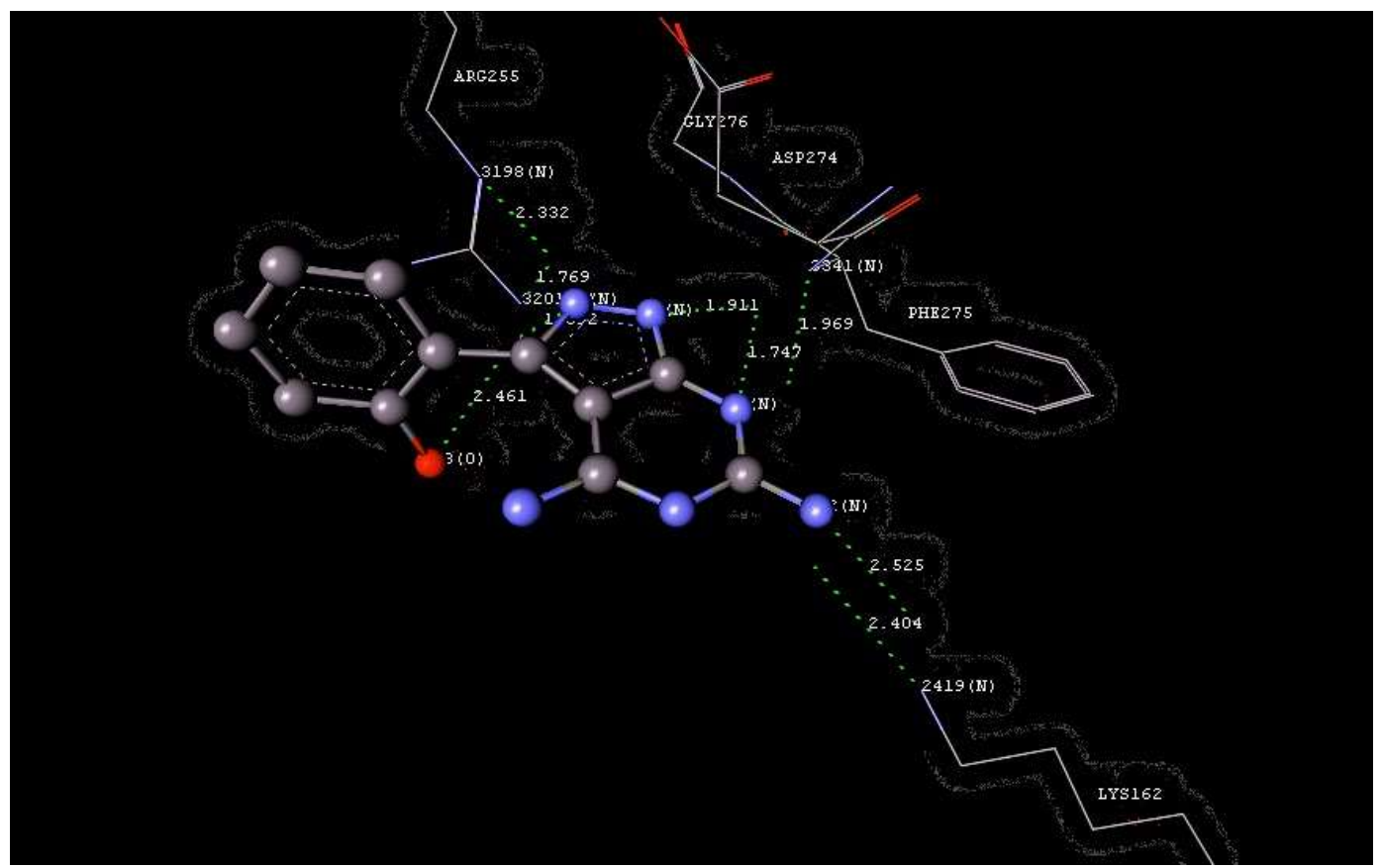

Fig.-7: Predicted Binding Pose of 2BMC with $\mathrm{A}_{3}$

Table-9: The interactions of $2 \mathrm{BMC}$ and $\mathrm{A}_{5}$

\begin{tabular}{c|c|c|c}
\hline Residue Atom & Ligand Atom & Distance & Interaction \\
\hline LYS162 2418C & $12 \mathrm{C}$ & 4.433 & Hydrophobic Interaction \\
\hline LEU178 2545C & $12 \mathrm{C}$ & 4.354 & Hydrophobic Interaction \\
\hline PHE275 3345C & $12 \mathrm{C}$ & 4.569 & Hydrophobic Interaction \\
\hline PHE275 16176H & $5 \mathrm{~N}$ & 2.417 & Hydrogenbond Interaction \\
\hline PHE275 16176H & $11 \mathrm{O}$ & 1.638 & Hydrogenbond Interaction \\
\hline
\end{tabular}


RASĀYAN J. Chem.

Vol. 13 | No. 3 |1555-1570| July - September | 2020

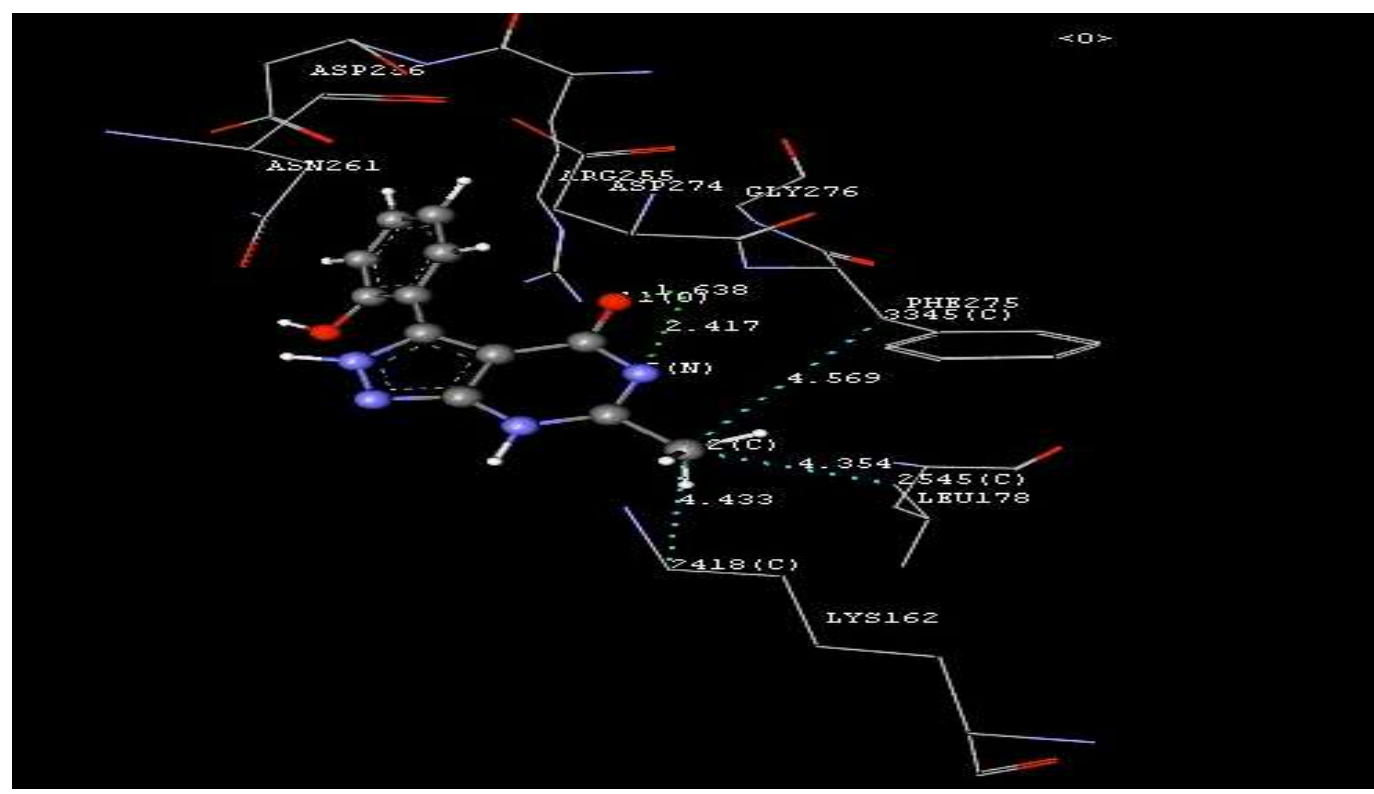

Fig.-8: Predicted Binding Pose of 2BMC with $\mathrm{A}_{5}$

Biological Evaluation

Anticancer Activity Assay

To evaluate the SAR, 10 compounds $\left(\mathrm{A}_{1}-\mathrm{A}_{11}\right)$ were prepared and studied for their anticancer activity. (Table-10). All synthesized compounds were evaluated for their anticancer activity against 2 cancer cell lines, K562 (leukemia), A549 (lung cancer) using MTT assay method. The parameter used here is $\mathrm{IC}_{50}$ which is the concentration required for $50 \%$ inhibition of cells.

The anticancer results are shown in Table-10 Compound $\mathrm{A}_{1}, \mathrm{~A}_{2}, \mathrm{~A}_{3}, \mathrm{~A}_{4}, \mathrm{~A}_{5}, \mathrm{~A}_{9}$ and $\mathrm{A}_{11}$ showed very good anticancer activity that supported the molecular docking studies. Especially, Compound $\mathrm{A}_{3}$ showed excellent inhibitory effect against A549 and $\mathrm{K} 562$ with an $\mathrm{IC}_{50}$ value of $0.04 \mu \mathrm{M}$. The result also showed that surprisingly compound $A_{6}$ and $A_{7}$ were found less potent than other compounds even though the docking studies showed fine scores. These results emphasize that pyrazolo[3,4-d]pyrimidine moiety may play an important role in regulating activity.

The SAR studies analysis, listed in the Table-10 showed that half of the synthesized compounds have been found to be potent against A-549 cell line of lung carcinoma. It is observed that compound $\mathrm{A}_{3}$ showed excellent activity with $\mathrm{IC}_{50}$ value of $0.04 \mu \mathrm{M}$. The other compounds $\mathrm{A}_{1}, \mathrm{~A}_{2}, \mathrm{~A}_{5}$ and $\mathrm{A}_{9}$ also showed better activity on $\mathrm{A}-549$ cell line too. Compound $\mathrm{A}_{3}, \mathrm{~A}_{2}$ and $\mathrm{A}_{1}$ are more cytotoxic than compounds $\mathrm{A}_{5}$ and $\mathrm{A}_{9}$ which shows that the electron-donating group at $4^{\text {th }}$ position is very important for a remarkable cytotoxic activity. In compounds $A_{3}, A_{2}$ and $A_{1}$ do have an electron-withdrawing group at $6^{\text {th }}$ position imino, thione and ketone functionality respectively, which led to a higher anticancer activity. Compound $\mathrm{A}_{5}$ and $\mathrm{A}_{9}$ have methyl and aryl group at $6^{\text {th }}$ position, which is a weak electron-donating group, decreased their activity against A-549 cell line. Compound $\mathrm{A}_{5}$ have ketone group at a $4^{\text {th }}$ position instead of phenyl group showed better activity than compound $\mathrm{A}_{9}$, which have the only hydrogen at $4^{\text {th }}$ position. The compound $\mathrm{A}_{4}, \mathrm{~A}_{6}$ and $\mathrm{A}_{7}$ did not show good inhibition for A-549 cell line.

Table-10: Cytotoxicity Assay of Compounds $\mathrm{A}_{(1-12)}$ on A-549, K-562 and MCF-7 Cell Line in $\mathrm{IC}_{50}(\mu \mathrm{M})$

\begin{tabular}{c|c|c|c|c}
\hline \multirow{2}{*}{ S. No. } & \multirow{2}{*}{ Compounds } & \multicolumn{3}{|c}{$\mathrm{IC}_{50}(\mu \mathrm{M})$} \\
\cline { 3 - 5 } & & $\mathrm{A}-549$ & $\mathrm{~K}-562$ & $\mathrm{MCF}-7$ \\
\hline 1 & $\mathrm{~A}$ & 0.25 & - & - \\
\hline 2 & $\mathrm{~A}_{1}$ & 0.12 & 0.08 & - \\
\hline 3 & $\mathrm{~A}_{2}$ & 0.09 & 0.1 & 0.22 \\
\hline 4 & $\mathrm{~A}_{3}$ & 0.04 & 0.04 & - \\
\hline 5 & $\mathrm{~A}_{4}$ & - & 0.22 & - \\
\hline 6 & $\mathrm{~A}_{5}$ & 0.20 & 0.08 & - \\
\hline
\end{tabular}


RASĀYAN J. Chem.

Vol. 13 | No. 3 |1555-1570| July - September | 2020

\begin{tabular}{c|c|c|c|c}
\hline 7 & $\mathrm{~A}_{6}$ & $>0.25$ & - & - \\
\hline 8 & $\mathrm{~A}_{7}$ & $>0.25$ & - & - \\
\hline 9 & $\mathrm{~A}_{9}$ & 0.17 & 0.17 & - \\
\hline 10 & $\mathrm{~A}_{11}$ & - & 0.16 & - \\
\hline 11 & Imatinib & 0.63 & 2.0 & 1.03 \\
\hline 12 & 5-fluoro uracil & 42.21 & - & 5.75 \\
\hline 13 & Cisplatin & 259.67 & - & \\
\hline
\end{tabular}

Only 2-pyrimidine thione (compound $\mathrm{A}_{2}$ ) has shown activity against breast cancer cell line while simple pyrimidine, 2-pyrimidone and 4-pyrimidone derivatives are inactive. Unsubstituted 4-pyrimidone did not give potency against lung carcinoma but was found to be active in chronic myeloid leukemia. C-2 position of pyrimidine in $\mathrm{A}_{3}$ was substituted with imine derivative yielded the most potent compound on the cell line for lung cancer and chronic myeloid leukemia. The substitution on phenyl group by $\mathrm{p}-\mathrm{OH}$ on $\mathrm{C}-2$ of $\mathrm{A}_{11}$ dramatically diminished the activity on lung cancer while the effect was not so prominent on leukemia cell line.

A comparable trend was also observed to K562 cell line shown in a Table-10. As for A-549 cell line, Compound $\mathrm{A}_{3}$ showed excellent activity to K562 cell line of leukemia. We found that almost all compounds showed very good activity against K562 cell line. The strong electron-withdrawing groups at $4^{\text {th }}$ and $6^{\text {th }}$ position in $A_{1}, A_{2}, A_{3}, A_{5}$ and $A_{11}$ showed significantly more potent activity. Without any group at $6^{\text {th }}$ position, it lowered activity in $\mathrm{A}_{4}$. $\mathrm{A}_{5}$ showed excellent activity than $\mathrm{A}_{4}$ with the $\mathrm{IC}_{50}$ value of $0.08 \mu \mathrm{M}$. The methyl group of $A_{5}$ was replaced with phenyl group in compound $A_{9}$, significantly lowered the activity. The synthesized compounds were found to be potent at lower micromolar concentration than the Imatinib, 5-fluoro uracil and Cisplatin. ${ }^{4-48}$

\section{Antibacterial and Antifungal Activity}

All synthesized compounds were evaluated for antibacterial and antifungal activity against four (two grampositive + two gram-negative) bacterial and three fungal species by broth's dilution method. All of them were compared with standard drug Ampicillin and Nystatin.

All of the compounds were screened for E-coli, P.Aeruginosa, S.Aureus and S.Pyogenus. and compared them with the standard drug Ampicillin (Graph-1).

Compounds $\mathrm{A}_{3}, \mathrm{~A}_{5}, \mathrm{~A}_{6}$ and $\mathrm{A}_{7}$ showed inhibition against $E$-coli bacterial species. The $\mathrm{C}-2$ position of 4pyrimidone was substituted with electron donating group $-\mathrm{CH}_{3}$ and $\mathrm{CH}_{2} \mathrm{SH}$ have been found potent inhibitor than all synthesized compounds in which compound $\mathrm{A}_{5}$ showed higher potency than Ampicillin with $62.5 \mu \mathrm{g} / \mathrm{ml}$ minimum inhibitory concentration. C-2 position of pyrimidine was substituted with imine, $\mathrm{CH}_{2} \mathrm{SH}$ and $\mathrm{CH}_{2} \mathrm{Cl}$ found to be equipotent with Ampicillin standard drug.

We found the potency for $E$-coli in following order: $\mathrm{A}_{5}>\mathrm{A}_{3}=\mathrm{A}_{6}=\mathrm{A}_{7}$

Compounds $\mathrm{A}_{3}, \mathrm{~A}_{5}, \mathrm{~A}_{6}, \mathrm{~A}_{9}$ and $\mathrm{A}_{11}$ showed good potency against $P$.Aeruginosa bacterial species. The $\mathrm{C}-2$ position of 4-pyrimidones and pyrimidine was substituted with groups but electron-donating groups $(=\mathrm{NH}$, $\left.-\mathrm{CH}_{3},-\mathrm{CH}_{2} \mathrm{SH}, \mathrm{C}_{6} \mathrm{H}_{5}, \mathrm{p}-\mathrm{OH}-\mathrm{C}_{6} \mathrm{H}_{4}\right)$ found to be active against P.Aeruginosa. We found that the $\mathrm{A}_{5}, \mathrm{~A}_{6}$ and $\mathrm{A}_{11}$ showed equal potency $(100 \mu \mathrm{g} / \mathrm{ml})$ and $\mathrm{A}_{3}$, $\mathrm{A}_{9}$ showed higher potency $(62.5 \mu \mathrm{g} / \mathrm{ml})$ than ampicillin. The potency order of compounds against P.Aeruginosa is as follows: $\mathrm{A}_{3}=\mathrm{A}_{9}>\mathrm{A}_{5}=\mathrm{A}_{6}=\mathrm{A}_{11}$

For S.Aureus bacterial species most of the compounds showed good potency except compound $\mathrm{A}_{1}$ and $\mathrm{A}_{2}$. The $\mathrm{C}-2$ position of 4-pyrimidone was substituted with electron donating groups $-\mathrm{CH}_{3}$ yielded the most potent compound on S.Aureus bacterial species. The pyrazole (Compound - A) have shown equal potency with a standard drug with ampicillin for $S$.Aureus bacteria. The compounds $\mathrm{A}_{4}, \mathrm{~A}_{6}$ and $\mathrm{A}_{10}$ compounds found equipotent to Ampicillin.

We found potency order for S.Aureus as follows: $\mathrm{A}_{5}>\mathrm{A}_{9}>\mathrm{A}=\mathrm{A}_{7}$

Only two compounds ( $\mathrm{A}_{5}$ and $\mathrm{A}$ ) were found to be equally potent against S.Pyogenus bacterial species to Ampicillin drug. All compounds were screened for C. Albicans, A. Niger and A. Clavatus fungal species and compared them with the standard drug Nystatin.

Only compound A found to be equipotent with standard drug nystatin with minimal bacterial concentration value of $100 \mu \mathrm{g} / \mathrm{ml}$ against $C$. Albicans. No other compound gave inhibition against $A$. Niger and $A$. Clavatus fungal species in comparison with standard drug nystatin. 
RASĀYAN J. Chem.

Vol. 13 | No. 3 |1555-1570| July - September | 2020

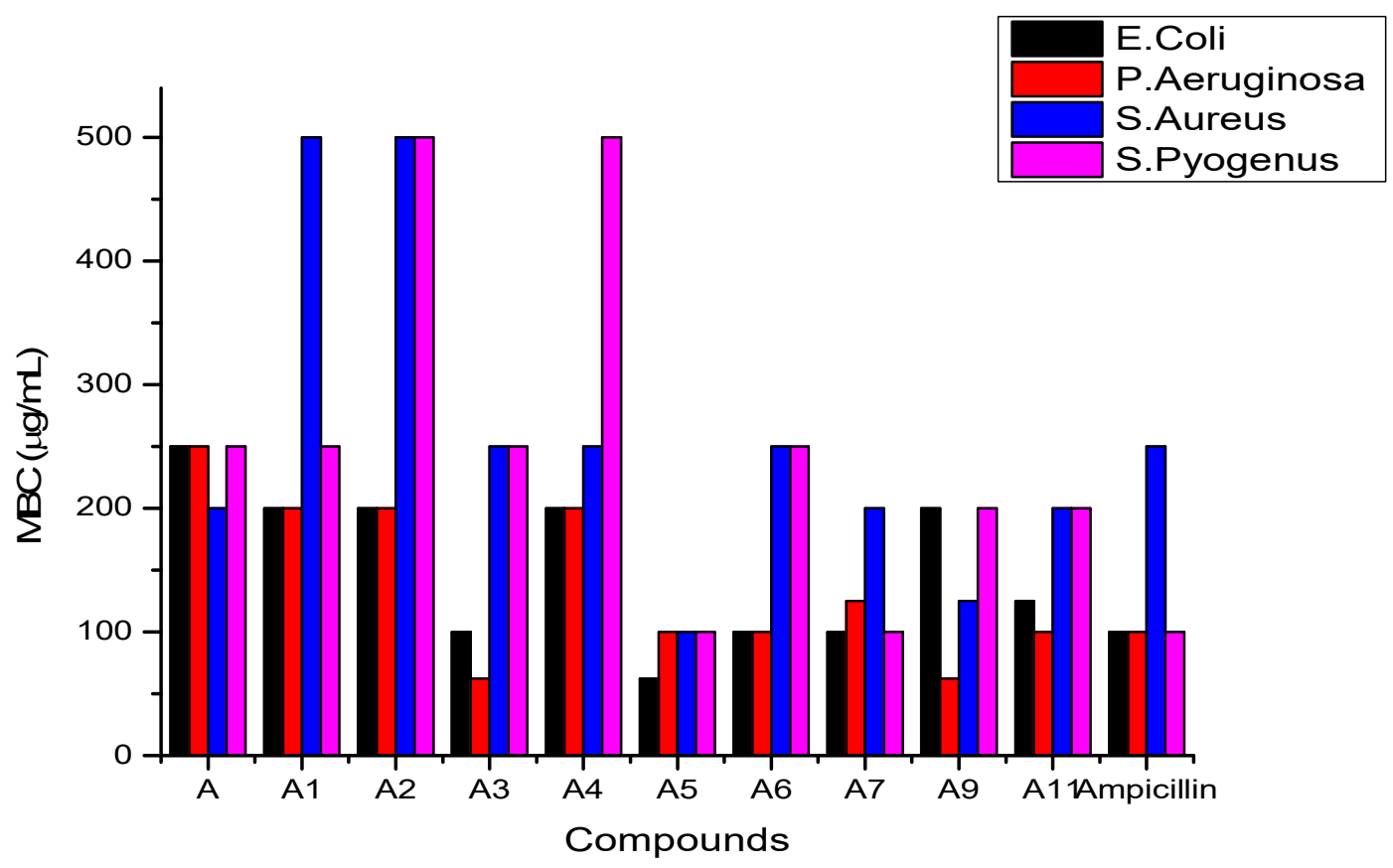

Graph-1: Graphical Representation of Antibacterial Activity of Synthesized Compounds (A-A $\left.\mathrm{A}_{11}\right)$

\section{Prediction of Pharmacokinetic Properties}

The pharmacokinetic analysis of the compounds under study was done by SwissADME (www.swissadme.ch) online tool. ADME analysis was carried using standard default protocol. ${ }^{49}$ The most important parameters and ranges are given in Table-11. The compounds were examined by Lipinski's rule of five, which has a profound effect on determining the drug-likeness of the compounds. Any orally active drug should not have more than four violations of Lipinski's rule. It was found that almost all the compounds followed Lipinski's rule of five. All the synthesized compounds have a molecular weight less than $300 \mathrm{~g} / \mathrm{mol}$ except $A_{11}($ Molecular weight = 320). All compounds have hydrogen bond donor and acceptor group less than 5 except $\mathrm{A}_{3}$.

SwissADME predictor for solubility was developed by SILICOS-IT on the scale of 0 to -10 . The more negative value of $\log S$ showed a decrease insolubility. Compound $A_{9}$ and $A_{11}$ found moderately soluble in water while the other compounds found to be highly soluble in water.

The liposolubility $\left(\log \mathrm{P}_{\mathrm{o} / \mathrm{w}}\right)$ prediction of compounds in ADME tool was calculated by WLOGP, a purely atomistic method based on the fragmental system of Wildman and Crippen. ${ }^{50}$ Lipophilicity, or LogP, influences a compound's behavior in biological processes pertinent to drug discovery such as solubility, permeability, or hepatic clearance. A LogP value of between 2 and 3 is more favorable to achieve permeability and first-pass clearance. ${ }^{51}$ All of the synthesized compounds showed the WLogP value less than 5 .

The skin permeability coefficient $(\mathrm{Kp})$ calculated in this tool was adapted from Potts and Guy which is corelated with molecular weight and lipophilicity. The more negative value of $\mathrm{Kp}$ shows less skin permeation. ${ }^{52}$ Compounds showed decreasing skin permeability by increasing molecular weight and lipophilicity.

The gastrointestinal absorption and blood brain barrier permeation (BBB) was predicted from BOILEDEgg model. It is found that moderately polar $\left(\mathrm{PSA}<79 \AA^{2}\right.$ ) and relatively lipophilic compound ( $\log \mathrm{P}$ from 0.4 to 6.0 ) has a high probability to access the central nervous system. ${ }^{5}$ All compounds showed high gastrointestinal absorption. Only two compounds, $\mathrm{A}_{9}$ and $\mathrm{A}_{12}$ showed $\mathrm{BBB}$ permeation for the blood brain barrier. 
RASĀYAN J. Chem.

Vol. 13 | No. 3 |1555-1570| July - September | 2020

Table-11: ADME Properties

\begin{tabular}{|c|c|c|c|c|c|c|c|c|c|c|}
\hline No & Cpd & $\begin{array}{l}\text { M.W. } \\
(\mathrm{g} / \mathrm{mol}) \\
<300\end{array}$ & $\begin{array}{c}\text { HBD } \\
<5\end{array}$ & $\begin{array}{c}\text { HBA } \\
<10\end{array}$ & $\begin{array}{c}\text { Lipophilicity } \\
\text { WLogP } \\
\text { O/W } \\
<5 \\
\end{array}$ & $\begin{array}{c}\text { TPSA } \\
\AA^{2}\end{array}$ & $\begin{array}{l}\text { W. S. } \\
\text { LogS } \\
\text { (SILICOS } \\
\text {-IT) }\end{array}$ & GIA & BBBP & $\begin{array}{c}\text { Log Kp } \\
\text { (Skin } \\
\text { permiation) } \\
\mathrm{cm} / \mathrm{s} \\
\end{array}$ \\
\hline 1 & $\mathrm{~A}$ & 200.20 & 3 & 3 & 1.24 & 98.72 & -2.91 & High & No & -6.50 \\
\hline 2 & $\mathrm{~A}_{1}$ & 243.22 & 4 & 4 & 0.61 & 120.68 & -3.66 & High & No & -7.75 \\
\hline 3 & $\mathrm{~A}_{2}$ & 259.29 & 4 & 3 & 1.98 & 135.70 & -3.86 & High & No & -7.42 \\
\hline 4 & $\mathrm{~A}_{3}$ & 242.24 & 5 & 4 & 0.73 & 127.46 & -3.81 & High & No & -7.68 \\
\hline 5 & $\mathrm{~A}_{4}$ & 228.21 & 3 & 4 & 1.02 & 94.66 & -4.02 & High & No & -7.24 \\
\hline 6 & $\mathrm{~A}_{5}$ & 242.23 & 3 & 4 & 1.33 & 94.66 & -4.41 & High & No & -7.33 \\
\hline 7 & $\mathrm{~A}_{6}$ & 274.30 & 3 & 4 & 1.30 & 133.46 & -4.53 & High & No & -7.30 \\
\hline 8 & $\mathrm{~A}_{7}$ & 276.68 & 3 & 4 & 1.61 & 94.66 & -5.04 & High & No & -7.10 \\
\hline 9 & $\mathrm{~A}_{9}$ & 288.30 & 2 & 4 & 3.39 & 74.69 & -6.62 & High & Yes & -5.83 \\
\hline 10 & $A_{11}$ & 320.30 & 4 & 5 & 2.39 & 114.89 & -5.94 & High & No & -6.88 \\
\hline
\end{tabular}

$\mathrm{Cpd}=$ compounds, M.W. = molecular weight, HBD $=$ Hydrogen bond donor, HBA $=$ Hydrogen bond acceptor, TPSA $=$ topological polar surface area, GI absorption $=$ Gastrointestinal absorption, BBBP $=$ blood brain barrier Permeation, GIA $=$ Gastrointestinal absorption,

\section{CONCLUSION}

Pyrazolo pyrimidines were designed and analyzed on molecular docking studies._Favorably Efficient and catalyst-free synthesis of 5-amino-3-(2-hydroxyphenyl)-1H-pyrazole-4-carbonitrile has been developed by grinding aldehyde with malononitrile followed by hydrazine hydrate in a solvent and catalyst-free condition. The synthesis of highly potent anticancer pyrazolo[3,4-d]pyrimidines has been developed in an efficient way such as solvent and catalyst-free solid fusion, acid-catalyzed solvent-free reaction conditions. An effortless work-up procedure and pre-preparation, easy handling of reaction and noticeable yield are the valuable features of these procedures. The compound 5-amino-3-(2-hydroxyphenyl)-1H-pyrazole-4carbonitrile (Compound A) showed good docking scores and interactions with 4MKC in docking study and gave an excellent $50 \%$ inhibition against A-549 cell line at $0.25 \mu \mathrm{M}$ concentration. Some of the synthesized compounds gave excellent inhibitory activity against lung carcinoma, chronic myeloid leukemia and breast carcinoma. The imino derivatization on pyrimidine $\left(\mathrm{A}_{3}\right)$ showed good docking scores with crystal structures of $2 \mathrm{BMC}, 1 \mathrm{QCF}$ and $4 \mathrm{MKC}$ and also shown excellent potency of $0.04 \mu \mathrm{M} \mathrm{IC}_{50}$ value against $\mathrm{K}-562$ and A-549 cell lines. The anticancer activity and virtual studies proved the hypothesis of designed structures. The compounds showed moderate antibacterial and antifungal activity compared to Ampicillin and Nystatin. The ADME studies for the synthesized compounds have shown to follow Lipinski's rules and good oral bioavailability.

\section{ACKNOWLEDGEMENT}

The authors are very thankful to the head of the chemistry department, V. N. S. G. University, Surat, Gujarat for providing laboratory facilities. The authors are thankful to SAIF, Punjab University, Punjab for spectral analysis. The authors are also thankful to the Department of Microbiology, Maratha Mandal's NGH Institute of Dental Sciences \& Research Centre for anticancer activities. One of the authors, Parnas S. Parmar gratefully acknowledges UGC for financial support as RGNF scheme.

\section{REFERENCES}

1. O. Shao-En, S. Monica, A. M. Adam, L. Xiaoyu, D. Kathy, K. D. Mary, D. R. Mania, K. Letian, W. Xiang, L.W. John, J. T. Nicola, N. K. Angela, A. M. Lisa, R. G. Todd, J. G. Robert, L. S. Stuart, A. C. Steven, PNAS, 106(12), 4617(2009), DOI:10.1073/pnas.0900191106

2. R. Rodriguez, K. M. Miller, Nature Review Genetics, 15, 783(2014), DOI: 10.1038/nrg3796

3. I. Peter, S. Christian, M. Achim, Nature Reviews Drug Discovery, 5(10), 821(2006), DOI: $10.1038 / \mathrm{nrd} 2132$

4. M. Congreve, R. Carr, C. Murray, H. Jhoti, H., Drug discovery Today, 8(19), 876(2003), DOI: 10.1016/S1359-6446(03)02831-9 
RASĀYAN J. Chem.

Vol. 13 | No. 3 |1555-1570| July - September | 2020

5. A. B. William, Nature Review Drug Discovery, 15, 275(2016), DOI: 10.1038/nrd.2015.21

6. A. Daina, V. Zoete, ChemMedChem, 11, 1117(2016), DOI: 10.1002/cmdc.201600182

7. S. Lapenna, G. Antonio, Nature Reviews Drug Discovery, 8(7), 547(2009), DOI: 10.1038/nrd2907

8. A. M. Jay, R. A. Marc, A. B. Pamela, B. Michael, R. B. Catherine, C. Chong-Hwan, S. C. Sarah, M. C. Philip, L. D. Charity, D. Deborah, G. Robert, A. H. Barbara, F. K., Robert, A. N. David, A. R. Karen, R. S. Susan, M. S. Lisa, S. Pieter, L. T. George, W. Peter, P. S. Steven, Journal of Medicinal Chemistry, 47(24), 5894(2004), DOI:10.1021/jm020455u

9. L. Ronghui, C. George, Y. Yang, J. C. Peter, L. Shengjian, L. Yanhua, A. Mary, R. Angel FuentesPesquera, L. E. Stuart, M. G. Lee, Bioorganic and Medicinal Chemistry, Letters, 17(16), 4557(2007), DOI: $10.1016 /$ j.bmcl.2007.05.092

10. M. Malumbres, M. Barbacid, Current Opinion in Genetics \& Deveopement, 17, 60(2007), DOI: 10.1016/j.gde.2006.12.008

11. W. W. Robert, O. Rajesh, P. H. Simon, R. W. Stephen, J. K. Nicholas, C. Claire, R. F. John, C. B. Madeleine, B. Alison, B. Elaine, F. B. Kate, C. B. Nigel, E. M. Kirsten, M. F. Kevin, M. H. Nicola, H. J. Frederic, A. M. F. Andrew, B. Thomas, G. Stephen, Clinical Cancer Research, 13(12), 3682(2007), DOI: $10.1158 / 1078-0432 . C C R-06-2979$

12. J. Zhang, L. Y. Priscilla, S. G. Nathanael, Nature Reviews Cancer, 9, 28(2009), DOI: 10.1038/nrc2559

13. K. Kentaro, H. Hisashi, I. Yuichi, A. Hiroyuki, Nature, 448, 561(2007), DOI: 10.1038/nature05945

14. F. Daniele, M. Jürgen, V. Mario, B. Rodrigo, A. Roberta, B. Daniela, B. Simona, C. Alexander, C. Ilaria, C. Paolo, C. Patrizia, C. Walter, F. Barbara, L. G. Maria, K. Jan, M. Aurelio, P. Enrico, R. Maurizio, R. Fulvia, S. Dino, S. Chiara, S. Paola, T. Roberto, Z. Paola, V. Paola, Journal of Medicinal Chemistry, 49(24), 7247(2006), DOI:10.1021/jm060897w

15. D. A. Paul, Oncogene, 24(32), 5005(2005), DOI: 10.1038/sj.onc. 1208752

16. L. Edmund Chun Yu, F. Anna, L. Rile, A. Gustavo, M. G. Norman, Cancer Research, 66, 4996(2006), DOI: $10.1158 / 0008-5472 . C A N-05-2796$

17. E. A. Harrington, D. Bebbington, J. Moore, R. K. Rasmussen, A. O. Ajose-Adeogun, T. Nakayama, J. A. Graham, C. Demur, T. Hercend, A. Diu-Hercend, M. Su, J. M. Golec, K. M. Miller, Nature Medicine, 10(3),262(2004), DOI:10.1038/nm1003

18. Y. Hua, O. Chien Chen, I. F. Richard, V. N. Santo, A. K. Patricia, Q. C. Jin, Cancer Research, 64, 463(2004), DOI: 10.1158/0008-5472.CAN-03-2907

19. K. Dong Chan, L. Yeo Ran, Y. Beom-Seok, S. Kye Jung, K. Dong Jin, C. Bong Young, Y. Kyung Ho, Europian Journal of Medicinal Chemistry, 38(5),525(2003), DOI:10.1016/S02235234(03)00065-5

20. B. Jean-Yves Le, P. Angela, T. Betty, B. Christina, B. Cheryl, W. Deping, C. Gisela, C. Jer-Hong, C. Jianhua, F. Junhua, N. Khanh, S. Laura, L. Leona, Z. Lin, C. Michael, C. Michael, T. Min, P. Nuzhat, Z. Shuo, L. Tony, T. Art, Bioorganic and Medicinal Chemistry Letters, 22(5), 2070(2012), DOI: 10.1016/j.bmcl.2012.01.019

21. L. Dow, Robert, K. Kevin, G. R. Schulte., U.S. Patent No. 5, 593, 997 (1997)

22. F. J. Giles, J. Cortes, D. Jones, D. Bergstrom, H. Kantarjian, S. J. Freedman, Blood, 109(2), 500(2007), DOI: $10.1182 /$ blood-2006-05-025049

23. L. Peng-Cheng, L. Huan-Qiu, S. Juan, Z. Yang, Z. Hai-Liang, Bioorganic and Medicinal Chemistry, 18, 4606(2010), DOI:10.1016/j.bmc.2010.05.034

24. G. D. Demetri, V. T. Van Oosterom, C. R. Garrett, M. E. Blackstein, M. H. Shah, J. Verweij, G. McArthur, I. R. Judson, M. C. Heinrich, J. A. Morgan, J. Desai, C. D. Fletcher, S. George, C. L. Bello, X. Huang, C. M. Baum, P. G. Casali, THE LANCET, 368, 1329(2006), DOI: 10.1016/S01406736(06)69446-4

25. H. Hurwitz, L. Fehrenbacher, W. Novotny, T. Cartwright, J. Hainsworth, W. Heim, J. Berlin, A. Baron, S. Griffing, E. Holmgren, N. Ferrara, G. Fyfe, B. Rogers, R. Ross, F. Kabbinavar, The New England Journal of Medicine, 350, 2335(2004), DOI:10.1056/NEJMoa032691

26. D. W. Sherbenou, B. J. Druker, The Journal of Clinical Investigation, 117, 2067(2007), DOI: 10.1172/JCI31988 
RASĀYAN J. Chem.

Vol. 13 | No. 3 |1555-1570| July - September | 2020

27. D. J. Slamon, B. Leyland-Jones, S. Shak, H. Fuchs, V. Paton, A. Bajamonde, T. Fleming, W. Eiermann, J. Wolter, M. Pegram, J. Baselga, L. Norton, The New England Journal of Medicine, 344, 783(2001), DOI: $10.1056 /$ NEJM200103153441101

28. M. Samet, K. Rahmi, I. Tuba, C. Ferdag, A. Ahmet. O. Salim, Europian Journal of Medicinal Chemistry, 78, 86(2014), DOI: 10.1016/j.ejmech.2014.03.033

29. A. M. Vijesh, M. I. Arun, S. Prashanth, S. Sundershan, F. Hoong Kun, Europian Journal of Medicinal Chemistry, 62, 410(2013), DOI: 10.1016/j.ejmech.2012.12.057

30. Y. H. Seham, Molecules, 18, 2683(2013), DOI: 10.3390/molecules 18032683

31. D. S. Patricia, M. Pablo, A. R. Maribel, S. S. Gabriela da, B. F. Henrique, H. de S. Alessandra, F. M. Carlos, B. Paulo, A. B. Robert, G. B. Helio, Z. Nilo, A. P. M. Marcos, European Journal of Medicinal Chemistry, 43, 1237(2008), DOI: 10.1016/j.ejmech.2007.07.018

32. M. Tsukasa, K. Takayuki, H. Atsushi, K. Hideki, S. Yasuhiro, T. Masahiko, M. Hideki, T. Hiroeki, S. Kazuya, M. Masao, O. Shiho, T. Tomoki, O. Hiroaki, O. Shinya, F. Nobutaka, Bioorganic and Medicinal Chemistry Letters, 23, 4557(2013), DOI: 10.1016/j.bmcl.2013.06.026

33. C. Wilson, A. C. Cleber, G. B. Helio, A. P. M. Marcos, Z. Nilo, Z., V. N. de S. Marcus, O. F. Isabela, P. P. S. Rodrigo, U. K. Antoniana, Bioorganic and Medicinal Chemistry Letters, 16, 649(2006), DOI: $10.1016 /$ j.bmcl.2005.10.033

34. E. R. Aymn, I. H. Mohamed, E. A. Randa, A. M. Jehan, M. E. A. Farouk, Bioorganic and Medicinal Chemistry, 16, 7102(2008), DOI:10.1016/j.bmc.2008.06.054

35. H. Bantwal Shivarama, M. Manjathuru, K. Mari Sitambaram, A. Padiyath Mohamed, S. Nalilu Sucheta, Bioorganic and Medicinal Chemistry, 14, 2040(2006), DOI: 10.1016/j.bmc.2005.10.053

36. B. Mehdi, B. Ghodsieh, V. Maryam, S. Ali, P. Mehdi, M. Mansour, P. Parvaneh, A. Maryam, European Journal of Medicinal Chemistry, 5, 647(2010), DOI: 10.1016/j.ejmech.2009.10.051

37. K. Mohammed, H. Abd El, D. M. Marko, B. E. Hala, European Journal of Medicinal Chemistry, 57, 323(2012), DOI:10.1016/j.ejmech.2012.09.031

38. A. Mukherjee, A. Sarkar, Tetrahedron Letters, 45, 9525(2004), DOI: 10.1016/j.tetlet.2004.11.016

39. R. Martin, M. R. Rivero, S. L. Buchwald, Angewandte Chemie International Edition, 45, 7079(2006), DOI: $10.1002 /$ anie.200602917

40. G. D. Chandrashekhar, K. D. Warad, D. G. Digambar, I. M. S. Mohammad, Journal of Chemical and Pharmaceutical Research, 8, 202(2016)

41. A. Ranjana, K. Vinod, K. Rajiv, P. S. Shiv, Beilstein Journal of Organic Chemistry, 7, 179(2011), DOI: $10.3762 /$ bjoc. 7.25

42. R. K. Nimesh, D. H. Dhaval, T. M. Prashant, K. P. Saurabh, European Journal of medicinal Chemistry, 45, 5056(2010), DOI: 10.1016/j.ejmech.2010.08.014

43. D. Alan, J. Bryan Griffiths, Cell and Tissue Culture for Medicinal Research., Wiley, London, UK, 62 (2000)

44. Z. Peilin, G. Wei Yi, T. Steven, S. D. Barbara, Molecular Cancer, 2, 1(2003), DOI: 10.1186/14764598-2-1

45. R. Aleksandar, T. Julian, F. Stefan, W. Jens zeller., Anticancer Research, 26, 2169(2006).

46. Zhao Minzhi, Huailei. Ma, PLoS One, 1(2015), DOI:10.1371/journal.pone.0131429

47. A. V. Patterson, H. Zhang, A. Moghaddam, R. Bicknell, D. C. Talbot, I. J. Stratford, A. L. Harris, British Journal of Cancer, 72, 669(1995), DOI: 10.1038/bjc.1995.392

48. O. S. John, C. Isolda Romero, S. Neil, A. L. Alexei, C. B. Guy, ChemMedChem, 9, 2791(2014), DOI: $10.1002 / \mathrm{cmdc} .201402285$

49. A. Daina, O. Michielin, V. Zoete, Scientific Reports., 7, 42717(2017), DOI: 10.1038/srep42717

50. A. W. Scott, M. C. Gordon, Journal of Chemical Information and Computer Sciences, 39, 868(1999), DOI: $10.1021 /$ ci9903071

51. S. S. S. J. Ahmed, V. Ramakrishnan, PLoS One, 7(7), 40654(2012), DOI: 10.1371/journal.pone.0040654

52. R. O. Potts, R. H. Guy, Pharmaceutical Research., 9, 663(1992), DOI:10.1023/A:101581031

[RJC-5692/2020] 